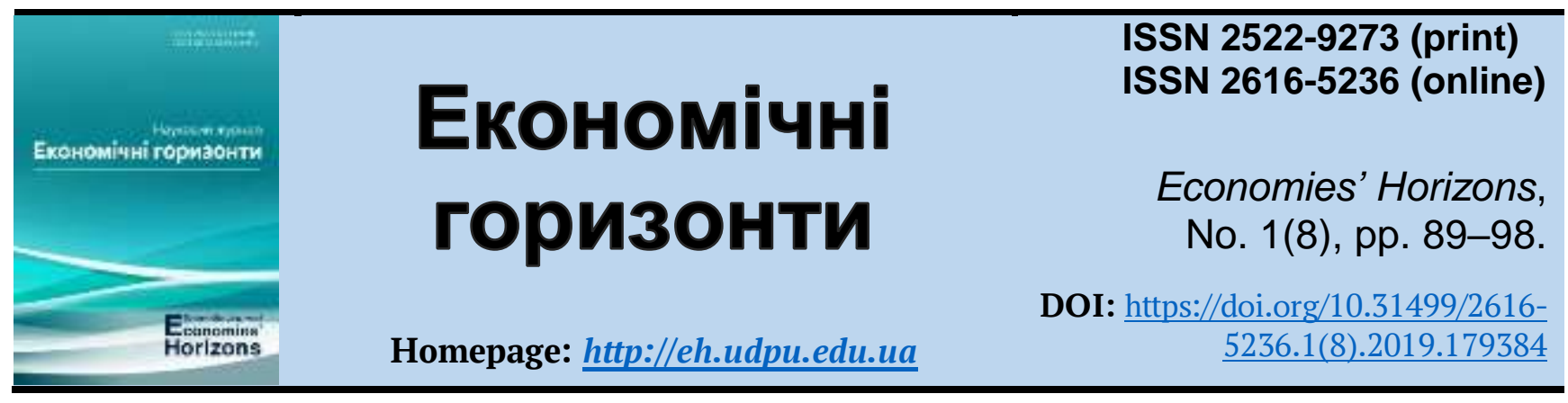

UDC 316.77:323.2:351

\title{
The modeling of communication between the community and authorities in the process of implementing the social projects as e-democracy and public administration
}

\author{
Anatolii A. Shyian ${ }^{1}$, Cand. Phys.-Math. Sc., Associate Professor \\ Anzhelika O. Azarova ${ }^{2}$, Cand. Techn. Sc., Professor \\ Liliia O. Nikiforova ${ }^{3}$, Cand. Ec. Sc., Associate Professor \\ Luydmila M. Tkachuk ${ }^{4}$, Cand. Ec. Sc., Associate Professor
}

Received: 17 March 2019

Accepted: 19 April 2019

\begin{abstract}
Shyian, A. A., Azarova, A. O., Nikiforova, L. O. and Tkachuk, L. M. (2019), "The modeling of communication between the community and authorities in the process of implementing the social projects as e-democracy and public administration", Economies' Horizons, no. 1(8), pp. 89-98, doi: https://doi.org/10.31499/26165236.1(8).2019.179384.
\end{abstract}

Abstract. The purpose of the research. Electronic democracy tools provide many new channels for interaction between the government and the community during the process of social projects implementation. This new factor for Ukraine requires significant communication between the authorities and the public. In this article the problem of power and the public interaction under the conditions of social projects implementation are considered in the context of e-democracy and public administration. Methodology. To aggregate the individual preferences the Hoteling model was used in the article. It allows proposing the new functional model for the interaction between authorities and the public. This model includes such compulsory components like electronic media and a group of experts and analysts. Results. The development of the public through the social projects implementation requires two conditions: a large number of people belonging to the "middle class" (there preferences not differ much from the median voter); all middle class voters should have full and objective information about the consequences of the decision. E-democracy and e-government must comply with these two conditions. In this sense we have to understand the D. Acemoglu and J. Robinson's thesis about that the political institutions (which are crucial for involving as much as possible the public to making decision) determine successful

\footnotetext{
${ }^{1}$ Vinnytsia National Technical University; Professor at the Department of Management and Information Systems Security; ORCID ID: https://orcid.org/0000-0002-5418-1498; e-mail: anatoliy.a.shiyan@gmail.com.

${ }^{2}$ Vinnytsia National Technical University; Professor, Deputy Dean of the Faculty of Management and Information Security by Scientific Work and International Cooperation; ORCID ID: https://orcid.org/0000-00033340-5701; e-mail: azarova.angelika@gmail.com.

${ }^{3}$ Vinnytsia National Technical University; Associate Professor at the Department of Enterprise Economics and Production Management; ORCID ID: https://orcid.org/0000-0002-7034-607X; e-mail: brasik@ukr.net.

${ }^{4}$ Vinnytsia National Technical University; Associate Professor, Deputy Dean of the Faculty of Management and Information Security by Educational Work; ORCID ID: https://orcid.org/0000-0001-9770-7851; e-mail: ludatkachuk2017@gmail.com.
} 
development of society. Activities of state and regional authorities are carried out under the condition of such projects implementation. Practical meaning. E-democracy requires society involvement at all stages of projects development and implementation. Taking into account this aspect in the proposed model of communication allows not only effectively transmit information from the authorities to the public about social project for analysis and substantiation but effectively influence the decisions of power structures. Prospects for further research. The dominant factor is the combination of experts and analysts, as well as their relationship with the society and power by channels of electronic media communication. It provides for the social group, in which the median voter is located, the obtaining of all needed information to making the optimal choice. The set of feedbacks between the public and the authorities allows for effective management of socio-economic development of society.

Keywords: modelling, interaction, power, public, public administration, electronic media, expert, analyst.

JEL Classification: E 20, F 21, H 10, J 28, Z 18.

Number of references: 11; number of tables: 0; number of figures: 3 ; number of formulas: $\mathbf{6}$.

\section{Моделювання комунікації між громадою та владою в процесі виконання соціальних проектів в контексті е-демократії та публічного адміністрування}

Стаття надійшла: 17.03.2019

Стаття прийнята: 19.04.2019
А. А. Шиян ${ }^{1}$, к. ф.-м. н., доцент

А. А. Азарова ${ }^{2}$, к. тех. н., професор

Л. О. Нікіфорова ${ }^{3}$, к. е. н., доцент

Л. М. Ткачук ${ }^{4}$, к. е. н., доцент

Shyian A. A., Azarova A. O., Nikiforova L. O., Tkachuk L. M. The modeling of communication between the community and authorities in the process of implementing the social projects as e-democracy and public administration. Економічні горизонти. 2019. № 1(8). C. 89-98. DOI: $10.31499 / 2616-$ 5236.1(8).2019.179384.

Анотація. Мета дослідження. Засоби електронної демократії надають велику кількість нових каналів для взаємодії між владою громадою. Ця нова для України обставина висуває потужні виклики до комунікації між владою та громадою. В статті поставлено задачу про взаємодію громади та влади в контексті електронної демократії та публічного управління. Методологія. Використано модель Хотелінга для агрегації переваг окремих людей, що дозволило запропонувати нову функціональну модель взаємодії органів ї влади та громади. Вона включає в себе електронні 3МІ та спільноту експертів та аналітиків як обов'язкові складові. Результати. Розвиток громади вимагає наявності двох умов: 1) достатньо великої кількості людей, які належать до «середнього

1 Вінницький національний технічний університет; професор кафедри менедюменту та безпеки інформаційних систем; ідентифікатор ORCID: https://orcid.org/0000-0002-5418-1498; e-mail: anatoliy.a.shiyan@gmail.com.

${ }^{2}$ Вінницький національний технічний університет; заступник декана факультету менеджменту та інформаційної безпеки з наукової роботи та міжнародного співробітництва; ідентифікатор ORCID: https://orcid.org/0000-0003-3340-5701; e-mail: azarova.angelika@gmail.com.

3 Вінницький національний технічний університет; доцент кафедри економіки підприємства та організації виробництва; ідентифікатор ORCID: https://orcid.org/0000-0002-7034-607X; e-mail: brasik@ukr.net.

${ }^{4}$ Вінницький національний технічний університет; заступник декана факультету менеджменту та інформаційної безпеки з навчальної роботи; ідентифікатор ORCID: https://orcid.org/0000-0001-97707851; e-mail: ludatkachuk2017@gmail.com. 
класу» (тобто переваги яких не сильно відрізняються від медіанного виборця); та 2) всі виборці «середнього класу» повинні мати повну та об’єктивну інформацію про наслідки рішення, яке вини повинні прийняти. Електронна демократія та електронне урядування повинні зосереджуватися навколо виконання цих двох умов. Саме в цьому сенсі слід розуміти тезу Д. Аджемоглу та Дж. Робінсона про те, що політичні інститути (які є вирішальними для залучення якомога більшого загалу людей до прийняття рішень) визначають успіх на шляху до розвиненого суспільства. Діяльність органів державної та регіональної влади здійснюється в рамках виконання окремих проектів. Практичне значення. Електронна демократія вимагає залучення громади на всіх етапах розробки та реалізації проекту. Врахування цього в запропонованій моделі комунікації дозволяє ефективно як доводити інформацію для аналізу та обгрунтування від влади до громади, так і громаді ефективно впливати на рішення влади. Перспективи подальших досліджень. Вирішальним чинником виступає сукупність експертів та аналітиків, а також їх зв'язок із громадою та владою каналами комунікації (в ролі яких виступають електронні 3МI). Тоді соціальна група, в якій знаходиться медіанний виборець, отримує всю повноту інформації, яка необхідна для здійснення оптимального вибору. А сукупність зворотних зв'язків між громадою та владою дозволяють здійснити ефективне управління соціально-економічного розвитком суспільства.

Ключові слова: моделювання, взаємодія, влада, громада, публічне управління, електронні 3МI, експерт, аналітик.

Кількість джерел: 11; кількість таблищь: 0; кількість рисунків: 3; кількість формул: 6.

\section{Introduction.}

The feedback from the public to the institutions of governance of the state, region or community is a decisive factor in ensuring the effectiveness of these institutions' activities. The absence or even the difficulty or delay in the transmission of information from the public to the institutions of governance and from the institutes of governance to society necessarily leads to negative consequences. Consequently, citizens are forced to go on strike because that is the only way they show their opinion to the leadership of the state or region.

During the social projects implementation e-democracy tools provide a large number of new channels for feedback from the public to the authorities. They also allow the justification of decisions from the authorities to the public. This new factor for Ukraine requires significant communication between the authorities and the community.

Thus, the study of the peculiarities of communication between the community and government in the process of social projects implementation under the conditions of electronic democracy is an actual scientific and important practical problem.

\section{Literature review.}

As it's shown in some scientific works (Acemoglu and Robinson, 2006; Acemoglu and Robinson, 2012) the necessary factor for the success of the public or region development, especially in the context of social projects implementing, is the presence of inclusive political and economic institutions.

Inclusive institutions (Acemoglu and Robinson, 2012) involve the widest possible population in participating in decision-making. Electronic democracy (e-democracy) is a powerful tool for the effective functioning of such institutions.

In the strategy for the development of the information society in Ukraine (Cabinet of Ministers of Ukraine, 2013), e-democracy is defined as "a form of social relations in which citizens and organizations are involved in state-building and public administration, as well as in local self-government through the wide use of information and communication technologies". 
It is emphasized in modern researches (Hrytsiak and Soloviev 2015; Malynovskyi, Hrytsiak, and Semenchenko, 2017), that in the general sense e-democracy implies involving the public in solving various socio-political tasks with the help of modern information technologies.

Today, Ukraine is in a state of hybrid war, when the informational and psychological influence from the outside sometimes affects the lives of citizens both at the state level and at the regional level (Felshtynskyi, and Stanchev, 2015).

As a result, electronic media become almost the only source of information for the population. Today, all mass media actively operate in electronic form, therefore, in our research the term "mass media" will be applied to their electronic form. Social networks are not yet controllable; besides, in emergency situations they usually carry out destructive influence, causing panic, violence and fatalism. So it does not help in emergency resolution. The psychological reasons of this are described in Varii's work (Varii, 2009), and consolidated effects (mostly destructive) are called in Lebon's research (Lebon, 2011) "crowd effects".

Thus, the study of the peculiarities of communicating the public with the authorities at different levels during the implementation of social projects in the conditions of electronic democracy is an actual scientific problem and important in the practical realization of the task.

\section{Methods.}

To aggregate the individual preferences, the Hoteling model was used in the article. It allows proposing the new functional model for the interaction between authorities and the public. This model includes such compulsory components like electronic media and a group of experts and analysts.

\section{Research objectives.}

The purpose of the article is to develop approaches to modelling the communication channels of the community and authorities un- der the conditions of social project implementing in the context of e-democracy and public administration.

\section{Results and discussions.}

\subsection{The modeling of making decision by the public.}

It is interesting to make up a mathematical model for describing the peculiarities of making decision by the public in the process of it communicating with the state and regional authorities. To do this, we modify the wellknown model of Hoteling (1929), which allows aggregating the individual preferences.

It is necessarily to describe the classical Hoteling's model on the basis of some researches (Acemoglu and Robinson, 2006; Hoteling, 1929; Shiyan, 2010) with modifying it for the conditions of our task.

We consider the individual preferences of people for their use when they make a common choice by voting. Thus, we will use the well-known "utility function" (Shiyan, 2010; von Neumann and Morgenstern, 1944), which allows analyzing the various alternatives. The utility feature helps a person to organize his thoughts, choose the best solutions, comparing them with each other. In other words, the utility function can reveal the benefits of one solution compared to others.

We have analysed the case when the utility function of an individual is convex upward and has one maximum (has one peak). This means that our individual chooses the only one opinion (decision) that is most appropriate for him from all possible choices. Every other decision (opinion), information and alternative the individual considers "less important" for himself. Consequently, the "further" this thought, this alternative lies on the "peak", so it is less important for him or the less he trusts her.

Example 1. A good sample can be demonstrated when one-dimensional set of possible individual thoughts regarding the causes of any political, economic or emergency situation. This could be, for example, a set of opinions such as "terrorists carrying out a terrorist act" due to "lack of state control" to the point of view "this happened on its own". 
There are individuals who are sincerely confident in the "conspiracy theory", while others are absolutely sure that "bad ecology is to blame". The more distant the opinion of the media, the less trusting in it is a person who holds a different opinion.

Mathematically, the "one-step" function of the individual's preferences can be defined in the next way. We denote $q$ as the preference of this individual and $Q$ as the set of possible preferences of all people. We consider this set to be "ordered", that is, there are operations "<" ("greater"), “=” (“equal” or “equivalent”) and ">" ("less") on the $Q$ set. This means that the individual is able to compare the thoughts (results of the decisions taken, the results of the choice made, etc.) among themselves. Denote by $V^{i}(q)$ - the indirect utility function for the $i-$ voter. This function allows the individual to determine which preference is most appropriate to him. In general, for each of $N$ individuals there is a function of utility.

Each individual, for example a voter $i$, has its own "perfect point" which is the value of a characteristic $q_{i}$, that gives the maximum value to its indirect utility function $V^{i}\left(q_{i}\right)$. In other words, it is a point for the $i$-voter that for any value of another preference $q$ there is a ratio $V^{i}\left(q_{i}\right) \geqslant V^{i}(q)$ for all $q \in Q$.

This is the definition for the "one-step" function of the utility of the individual ("voter"), which is also called the "one-peak" function of preferences when individuals make their social choice.

It is noteworthy to introduce the concept of "median" individual. The median individual is called an individual $M$, for which the number of individuals with individual preferences satisfying the relationship $q_{i}<q^{M}$ is the same as the number of voters whose individual preferences satisfy the relationship $q_{i}>q^{M}$. In other words, the "median" individual divides all people into "two half". The first half consists of individuals whose preferences are less important for the median voter, and the other vice versa.
The wide application of the aforementioned approach to the description of social choice is based on the median voter's theorem (MVT) (Hoteling, 1929). The formulation of the theorem is given in the research of Acemoglu and Robinson (Acemoglu and Robinson, 2006, p. 94) and a translation into Ukrainian (Shiyan, 2010, p. 64).

The median voter's theorem of Hoteling. What is interesting in this data is that a set of possible choices for an individual $Q \subset R$, so $q \in Q$ is the individual choice, and $M$ is the median individual who chooses the ideal point $q^{M}$. If all individuals have the one-peak functions of $Q$, then:

1) $q^{M}$ always wins any other alternative $q^{\prime} \in Q$ if $q^{\prime} \neq q^{M}$ at pair competition;

2) $q^{M}$ is always the winner in a direct voting with an open list.

\subsection{The modeling of communication} between the community and authorities during the social projects implementing.

It is necessary to apply MVT to modeling of communication between the community and authorities during the social projects implementing in the context of e-democracy and public administration.

Most of members of the society believe that the aggregated set of human preferences is formed by the media now. Caused by development of e-democracy, the intensity of this process will only grow. Using MVT proves that the main contribution to public opinion is made by the median individual. Therefore, the formation of the median individual "necessary" thought is an important component of the interaction of management structures and mass media both at the national and regional levels.

It should be emphasized that the choice of median individual $q_{m}$ does not match, as a rule, with the mean $q_{s}$ of a possible choice for all individuals. The possible situations can be analyzed in fig. 1.

In fig. 1 a) the value $q_{s}$ of the possible choice's average is equal to the value $q_{m}$ of the 
choice of median individual. This situation occurs as a rule in cases where the preferences of people are evenly distributed over the whole range of possible preferences.

a)

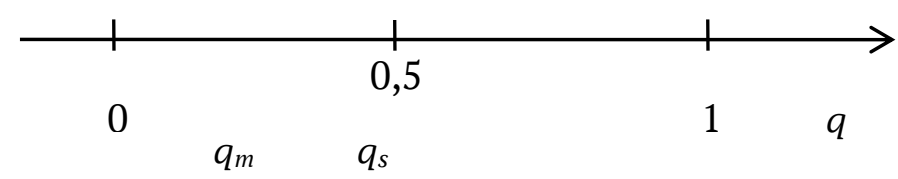

b)

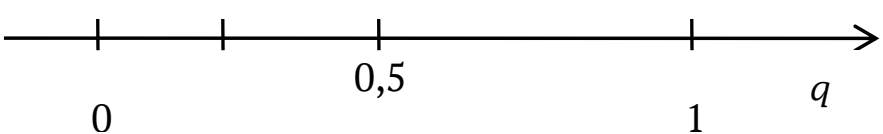

c)

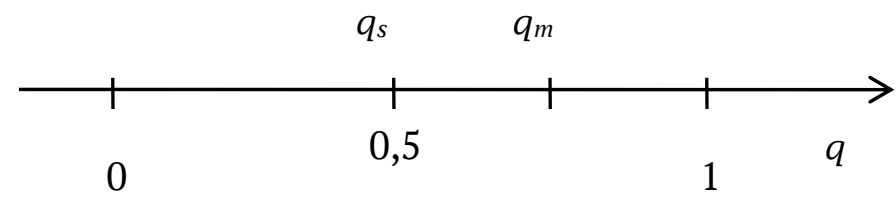

Fig. 1. The ratio between the average value of the possible choice and the choice of the median individual

Fig. $1 \mathrm{~b})$ shows the case when the preferences of the median individual $q_{m}$ are smaller and shifted to the left than the possible choice's average $q_{s}$. It means that most individuals choose less value of the preferences than the average. Fig. $1 \mathrm{c}$ ) shows an inverse case.

\subsection{Methods of using the model for the} community and government communication.

During communication between state and regional authorities, as well as the community it is important to create such a public opinion that will help society in its effective development, primarily by implementing social projects and will eliminate the unwanted deviations (for example, the negative consequences of emergencies). The most powerful channel for this is the media.

It should be noted that the electronic communication channel between the community and government provides a unique (now there is only one) opportunity for Ukraine to justify those decisions which are made by state and regional authorities. Moreover, only the electronic communication channel is capable to provide an effective feedback from the public to the authorities at the stages of discussing proposals and analyzing the consequences of proposed government decisions. From this position, such a method of using electronic mass media becomes the most important factor of $\mathrm{e}^{-}$ democracy in Ukraine.

The Hoteling's theorem MVT is, in essence, the main model that describes the mechanism of making decision by the community. It has led to the emergence of a concept of "middle class". To be able to reliably forecast the public decisions we need information on the preferences of those individuals who are located near the "medical voter". And the more preferences of this society do not differ much from the median voter's preferences, the more reliable will be the prediction of the public decision.

Another limitation of using the Hoteling's theorem is that individuals must consciously make their choices. Thus, they should have full and objective information about the consequences that follow from it.

Thus, forecasting the future development of the society requires, in essence, the existence of two conditions:

1) the presence of a large number of people belonging to the "middle class", the choice of which does not differ from the choice of the median voter;

2) all "middle class" voters should have full and objective information about the consequences of their decision.

E-democracy and e-government 
(Hrytsiak, and Soloviov, 2015; Malynovskyi, Hrytsiak and Semenchenko, 2017) should focus precisely on the implementation of these two conditions. In particular, the condition of increasing the "middle class" belongs mainly to economic conditions. However, economic conditions (more precisely, economic institutions) are the result of the public choices. In this very sense we should understand D. Acemoglu and J. Robinson's (2012) thesis that the political institutions (which are crucial for involving as much as possible the public to making decision) determine successful development of society.

Today, in the post-Soviet countries, the electronic communication channel between the community and the government is used inefficiently. For example, the operation of such a channel in Ukraine can be represented by the diagram in fig. 2.

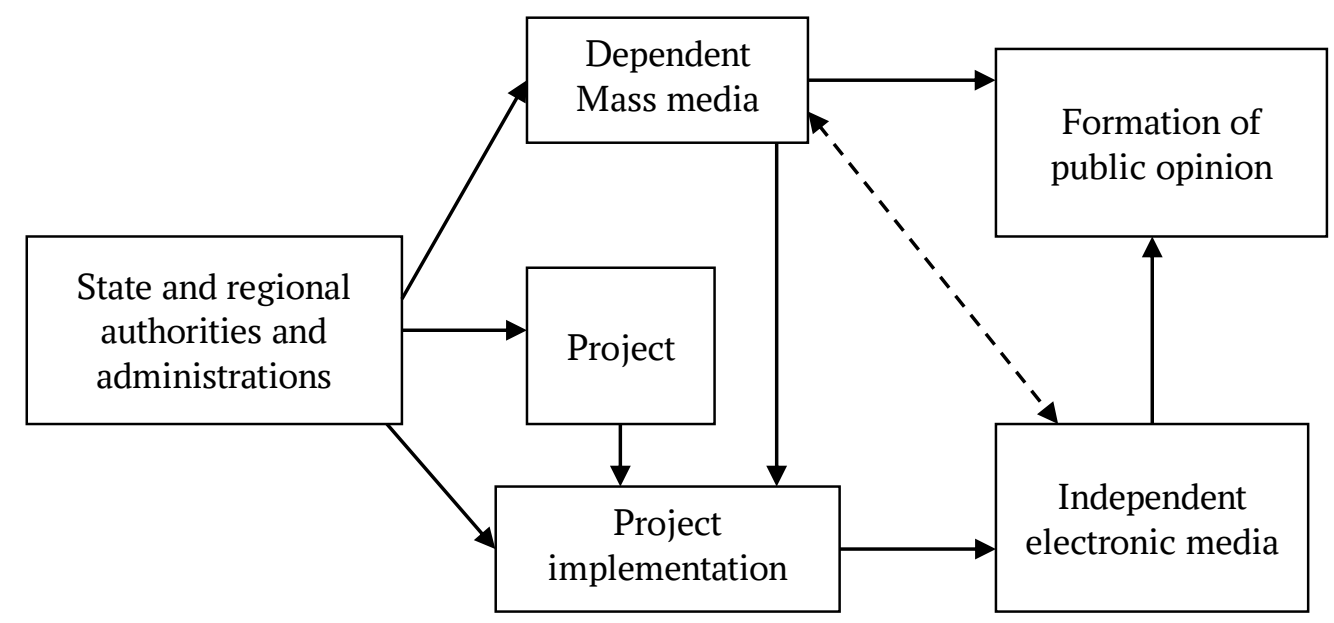

Fig. 2. The existing model of the functioning of communication between society and the power

The community might propose the state, regional authorities and administrations a specific project for consideration. For example, the expenses of the appropriate regional budget: the state budget in Ukraine, as a rule, is not put up for public discussion. Electronic media inform the public about this project. Unfortunately, such informing is carried out without almost analytical support. Besides of this, employees of state and regional authorities and administrations often act as "experts". So they are clearly interested people. Finally, the media themselves often act as stakeholders, defending the interests of their owners. This is the reason of that the information which is conducted to society is incomplete and distorted (biased). And even the presence in Ukraine of a sufficiently large number of different electronic media is not capable of helping citizens obtain objective information, because for this it's necessary to make serious analytical study.
And this requires from the citizen not only significant time resources, but also substantial analytic skills.

Similar problems occur after the implementation of state project and regional authorities and management. In fact, they appear in the media only in case of "necessity", as a result of a request from the media. The mass media themselves often does not interest in the opinion of society (with the exception, of course, of the election period). In particular, the so-called "public discussions" of projects proposed by the authorities, in the media have only declarative character with no reaction or real argumentation and justification by the authorities for society. Authorities, as a rule, are limited to words such as "taken into account", without specifying exactly what is taken into account.

However, today there are also independent electronic media. For example, YouTube, 
Facebook, Wikipedia, Live journal and many others. Moreover, a number of dependent media belong to business representatives, which can be opposition to the government. All these electronic independent of the authorities media actively influence the formation of public opinion in a country or region.

In addition, dependent and independent media also influence each other, which is indicated by a dotted line in fig. 2. For example, dependent media should react to special for the state and regional authority's scenarios, which are distributed by the independent media. Conversely, independent media often react to stories that appear in "pro-government" media (for example, in the form of "investigations").

Thus, the analysis which is carried out shows that today in electronic media (both dependent and independent) there is simply a huge amount of unstructured information. Moreover, only a few numbers of informational scenarios are analytical materials. Most of the information scenarios have only emotional influence to public.

Let's describe the model of channel operation for optimal communication between the authorities and the public during implementing an social project, which meets the requirements of e-democracy (Hrytsiak, and Soloviov, 2015; Malynovskyi, Hrytsiak and
Semenchenko, 2017). The main subjects of communication (Cabinet of Ministers of Ukraine, 2013; Hrytsiak, and Soloviov, 2015; Malynovskyi, Hrytsiak and Semenchenko, 2017) are the power and the public, and the main actors are the media (which today are virtually all electronic) and public opinion (which reflects the information processes in the society). Today in Ukraine there is not another very important participant of the information process - experts and analysts.

The creation of formal (integrated into existing state and regional authorities) and informal expert and analytical structures is very important task today. Below is a diagram of the functioning of such expert and analytical structures as a necessary and key component of the channel of interaction between government and society. Actually, without the functioning of such expert and analytical structures, the formation and functioning of inclusive (including) political, social and economic institutions in society is impossible (Acemoglu and Robinson, 2012).

Scheme of the functioning of the communication channel between the government and society, taking into account dependent and independent expert and analytical structures, is presented in Fig. 3.

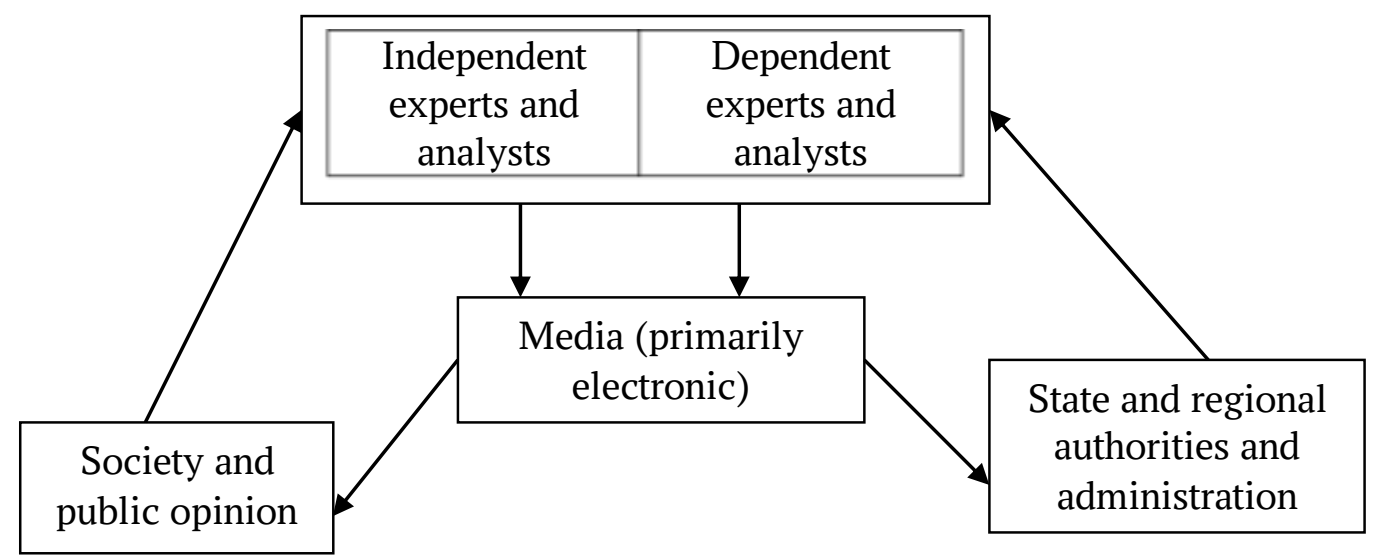

Fig. 3. The scheme of communication between government and society

Such scheme represents the channels of control (from government to community) and feedback (from community to government). It is extremely important that these connections do not proceed directly, but involve both expert-analytical structures and the mass media.

Society is able to influence power through such channels.

1. Society forms public opinion. 
2. Independent from the government experts and analysts identify public opinion and public desires and transform them into clearly defined tasks that society sets to the authorities. It also provides the necessary analysis and justification. All these are transmitted to mass media.

3. The media, and above all the electronic media, show these tasks to the community and the authorities.

4. The government is aware of the importance of this task for society and begins to develop methods for its solution.

In some cases, society can adjust the formulations of tasks that have been developed by independent experts and analysts.

The authorities always need the support of the society, including the correction of the solutions proposed by the authorities. This process is shown in the scheme of the fig. 3.

1. The government receives information from the media about what tasks are important to society.

2. The government proposes possible solutions and sends them to expert and analytical structures dependent on the authorities.

3. Dependent expert and analytical structures transmit to the media the results of analysis and expertise of solutions proposed by the authorities.

4. The society gets the variants of decisions, and forms the corresponding public opinion.

5. Public opinion is identified by independent experts and analysts who are preparing a rationale for the fact that a solution has been achieved to exactly the task that the society was concerned about; and convey the results to the media.

6 . The society agrees with the decision of the authorities or corrects its task for the authorities.

7. The authorities start to implement the decision approved by the public and the authorities or begin to propose new options.
The basic variants of the operation of such a channel of communication between government and the community are described above. In the general case, the channel operation scheme presented in Fig. 3, provides many interesting variants for the interaction of government and society.

The variety of different forms of mass media, primarily electronic, provides both to the authorities and the society enormous opportunities for increasing the effectiveness of the management.

Example 2. Another interesting fact is that during the interaction between the authorities and the public other sources of influence on public opinion can also be widely used. For example, movies are very effective. In particular, information about possible natural or technological catastrophes, their prevention and liquidation of consequences is widely used in Japan, South Korea, the United States and several other countries in the form of movieactions, movie-disasters, etc. Also, the literature of the relevant genres is effectively used.

Thus, the application of the proposed channel model for optimal communication between the authorities and the public during the implementation of social projects allows not only to transfer effectively information for analysis and substantiation from the government to the community but also to the decisions made by the government. A main factor here is a set of experts and analysts, as well as their relationship with the community, communication channels (like the electronic media) and authorities.

As a result of such a model, the median voter (i.e. the social group in which the median voter is located) gets all the information he needs to make the best choice. The set of feedbacks between the community and the authorities allows effective management of socioeconomic development.

\section{Conclusions.}

The problem of communication between 
the community and government during implementing the social project in the context of edemocracy and public administration is proposed. The model of making a common solution for aggregating the preferences of individuals is adapted to the conditions of the task. It allows proposing the functional model for interaction between state and regional authorities and the community.
The described communication channel includes electronic media and the community of experts and analysts as compulsory components. It enables creation an effective system of feedbacks between the authorities and the community which allows to make optimal decisions and to control the socio-economic development of society.

\section{References}

Acemoglu, D. and Robinson, J. A. (2006), Economic origins of dictatorship and democracy, Cambridge University Press, Cambridge, USA, 416 p.

Acemoglu, D. and Robinson, J. A. (2012), Why nations fail: the origins of power, prosperity, and poverty, Crown Publishers, New York, USA, 400 p.

Cabinet of Ministers of Ukraine (2013), Order of the Cabinet of Ministers of Ukraine "On Approval of the Strategy of the Information Society Development in Ukraine”, available at: https://zakon.rada.gov.ua/laws/show/386-2013-\%D1\%80?lang=en (Accessed 10 March 2018).

Felshtynskyi, Yu. and Stanchev, M. (2015), Tretia svitova: bytva za Ukrainu [Third World: The Battle for Ukraine], Nash format, Kyiv, Ukraine, 456 p.

Hoteling, H. (1929), “Stability and competition”, Econiomic Journal, vol. 39, no. 153, pp. 41-57.

Hrytsiak, N. V. and Soloviov, S. G. (2015), Elektronna demokratiia [Electronic democracy], NADU, Kyiv, Ukraine, $66 \mathrm{p}$.

Lebon, G. (2011), Psihologija narodov i mass [Psychology of peoples and masses], Akademicheskij proekt, Moskow, Russia, 238 p.

Malynovskyi, V. Ya., Hrytsiak, N. V. and Semenchenko, A. I. (2017), Kontseptyalni zasady elektronnogo yriadyvannia ta elektronnoi demokratii [Conceptual Principles of Electronic Governance and Electronic Democracy], FOP Moskalenko O. M., Kyiv, Ukraine, 70 p.

Shiyan, A. A. (2010), Upravlinniia rozvytkom sotsialno-ekonomichnykh system. Teoriia igor: osnovy ta zastosuvannia v ekonomitsi ta menedzhmenti [Management of the development of socio-economic systems. Theory of Games: Fundamentals and Applications in Economics and Management], VNTU, Vinnytsia, Ukraine, $162 \mathrm{p}$.

Varii, M. Y. (2009), Psykhologiia [Psychology], Tsentr Uchbovoi Literatury, Kyiv, Ukraine, 288 p.

von Neumann, J. and Morgenstern, O. (1944), Theory of Games and Economic Behavior, Princeton University Press, Princeton, USA, 680 p.

Цей твір ліцензовано на умовах Ліцензії Creative Commons «/з Зазначенням Авторства - Некомериійна 4.0 Міжнародна» (CC BY-NC 4.0). This is an open access journal and all published articles are licensed under a Creative Commons "Attribution-NonCommercial 4.0 International" (CC BY-NC 4.0). 